\title{
THE ROLE OF SOCIAL CAPITAL IN IMPROVING INNOVATIVE BEHAVIOUR AND HUMAN RESOURCES PERFORMANCE IN SEMARANG REGENCY GOVERNMENT
}

\author{
Ema Puspitosari $1^{*}$, Heru Sulistyo ${ }^{2 *}$
}

\footnotetext{
* Affiliation:

${ }^{1,2}$ Magister Program of Management Unissula
}

\begin{abstract}
:
The purpose of this study was to test a model in which social capital and information technology predict innovative behaviour and human resource performance. A total of 105 respondents completed questionnaires on social capital, information technology, innovative behaviour, and human resource performance. Results from structural equation modeling based smartPLS 3.0 confirmed that 1 ) social capital was positively related to innovative behaviour and human resource performance; 2) innovative behaviour was positively related to human resource performance; and 3) information technology moderated the relationships between innovative behaviour and human resource performance.
\end{abstract}

Keywords: Social capital, Innovative behaviour, Information technology, Human resource performance.

\section{INTRODUCTION}

HR or human resources in today's globalization era is said to be very important for organization, as HR is responsible for an organization run, with its good performancethe organization can reach its competitiveness in globalization era when the competition is very stiff (Balkar, 2015). One human resource who is satisfied with his or her job tends to show positive manner in work, therefore the organization needs to guarantee HR satisfaction by giving them optimum support so that organization's success can be achieved (Robbins, 2016).

Innovative behaviour is the most important factor in improving HR performance, it will be getting easier to implement optimally when it is supported by excellent information of technology. Several researches have been conducted as regards innovative behaviour towards work by some researchers, regardless controversy in their finding. Froiland et al. (2012) said that well innovative behaviour will affect a human resource performance improvement. In contrast, Loof and Heshmati (2002) said that innovative behaviour does not affect a human resource performance improvement. This research is trying to test the influence 
of innovative behaviour and performance by using information technology variable as moderation variable. Pekkanen ( 2012) said that information technology can reinforce HR performance. In accordance, innovative behaviour can be easily well implemented if it is supported by excellent information technology.

Other problems in this research are in line with reality that shows HR poor performance such as HR does not show empathy when other officers need assistance, HR still acts like "supervisor" when they do not serve properly, and individualistic manner among HR is still considered to be high. The problem happened in Setda of Semarang Regency is that there is an increasing trend for absence level of HR, it is noted that HR absence data in Setda of Semarang Regency in 2014 is $1,06 \%$, in 2015 it is increasing to be $1,14 \%$ and in 2016 it is increasing more to be $1,17 \%$, while absence level that is still tolerable as much as $0,75 \%$. It becomes an initial indicator that may affect HR performance.

\section{LITERATURE REVIEW HR Performance}

Generally, performance is an output measurement resulted through input. Performance is a company commitment to reach targeted goal that is supposed to be achieved by a company or organization's human resources (Betul, 2015). Robbins (2016) showed that aperformance can be measured through productivity, HR turnover, citizenship and human resources satisfaction.

Performance can not stand alone, instead it is closely related to work compensation and satisfaction. Performance is backed up by skills related to individual involved. The point is that HR performance is influenced by self ability, self willingnes, and the vicinity's support for better job's sake, therefore it needs to be backed up by brilliant human resources owned in focusing all abilities for organization progress. An individual human resource is supposed to have good confidence to achieve high performance. In addition, someone's ability should be better fit the work characteristic that will be executed.

Human resources performance is measured through 6 criteria for example independence, work commitment, punctuality, effectiveness, quality and quantity. Human resources performance is a success of in individual human resource to execute work activities. Performance itself is a work result done by human resource in a certain period. The performance achieved that is expected is also influenced by cooperation level done by human resources.

\section{Social Capital}

Social capital measures a new concept to measure a quality in a relation that becomes a community in society or organization. Social capital is considered in a tool in social structure that shapes an element which influences relation interaction among human in a relation that makes social structure in a useful state (Gagliardi and Percoco, 2013).

Social capital indicator covers 1) Cognitive dimension (for example having commitment to achieve organization goal and run organization totally); 2) Relational dimension (for example work seriously and teamwork spirit); and 3) Structural dimension (for example considering information and ideas in executing work task). Research done by Jmshidi and Kenarsari, (2015) showed that social capital positively affects HR innovative behaviour. 
Ozdemir dan Demirci (2012) said that HR who posseses good social skill is able to improve innovative behaviour. Petrou and Daskalopoulou (2013) showed that innovative behaviour will improve when HR is able to improve social capital. Jamshidi dan Kenarsari (2015) said that social capital has positive influence to innovative behaviour. This result is agreed by Petrou and Daskalopoulou (2013) who show that social capital has positive influence to innovative behaviour. Based on Ozdemir dan Demirci's research (2012); Petrou and Daskalopoulou (2013); and Jamshidi and Kenarsari (2015) can be formulated in a hypothesis as follows:

\section{H1: When social capital is increasing, then innovative behaviour is getting increased}

Social capital for organization shows an active instrument in social organization like norms, social beliefs, and links that facilitates mutual coordination and cooperation (Ali et al., 2013). Social capital is related to social aspect, and HR individual facilities in that structure. Research conducted by Ali et al. (2013) showed that social capital positively influences HR performance.

Aslam et al. (2013) said that HR who have good social capital can improve their performance. Turner (2011) showed that HR performance will improve when they can improve social capital. Ali et al. (2013) said that social capital has positive influence on HR performance. This result is agreed by Turner (2011) who showed that social capital has positive influence on HR performance. Based on Aslam et al.'s Research (2013); Turner (2011); and Ali et al. (2013), it can be formulated hypothesis 2 as follows:

\section{H2: When social capital is increasing, HR performance is getting increased}

\section{Innovative Behaviour}

Innovative behaviour is a process that shows an individual ability to work by making use of energy from a good innovation in communicating based on an individual's intellectual capital towards other individuals (Bysted, 2013). Innovative behaviour is a process from several individuals attempted to be able to work innovatively by using strong innovation skill to present individual's intellectual capital to other individuals (Xiangyin dan Zheng, 2014).

Innovative behaviour understands an individual's behaviour who is voluntarily working by using powerful innovation for the sake of organization's development. Indicator for innovative behaviour according to Bysted (2013) is to think creatively, enthusiastic to do new things, prioritise work execution, and behave innovatively.

Gagliardi dan Percoco (2013) said that HR who is working innovatively can improve their performance. Bysted (2013) showed that HR performance will improve when they can work innovatively. Froiland et al. (2012) said that innovative behaviour has positive influence on HR performance. This research is agreed by Bysted (2013) who showed that innovative behaviour has positive influence on HR performance. Based on Gagliardi and Percoco's research (2013); Bysted (2013); and Froiland et al., (2012), it can be formulated hypothesis 3 as follows:

H3: When innovative behaviour is increasing, HR performance is getting increased 


\section{Information Technology}

Information technology is something used to create information system, it consists of hardware and software used to implement computer based-system (Pekkanen, 2012).

Business environment development that is very dynamic influences every organization, whether it is big organization, middle or small organization. Jahanian and Asadi (2012) said that radical changing system will significantly influence on business development, so that most well prepared strategies created in advance will not be working well. Therefore, new strategy choice and decision is needed for organization to be more competitive.

Similar statement is also said by Pekkanen (2012), it is said that system influences competition for position in an industry. Organization effort to maintain its existence and development in global business environment depends on organization competence in making use of technology, especially accounting information system, to conquer various obstacles. Ruey-Jer et al. (2008) showed that information technology has moderated influence on innovative behaviour towards HR performance.

Pekkanen (2012) showed that information technology has moderated innovative behaviour influence towards HR performance. Based on the research of Pekkanen ( 2012); Jahanian and Asadi (2012); and Ruey-Jer et al. (2008), it can be formulated hypothesis 4 as follows:

\section{H4: Information Technology has moderated innovative behaviour towards HR performance}

Based on literary research and empirical research result from the previous research, then the empirical research model that can be proposed in this research is:

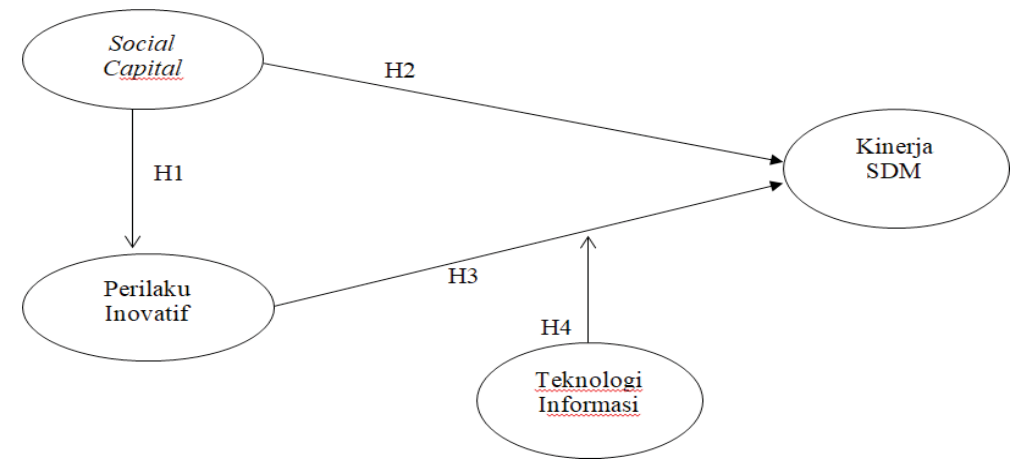

Picture 1. Empirical Research Model

\section{RESEARCH METHOD}

This research is using "Explanatory research" or a research that is focusing on explaining, it means this research is reasserting on the relation among research variables by testing hypothesis, the explanation contains description but the focus of attention is on the relation among variables (Kumar, 2005).

Data collection method used in this research is by using questionnaire. Questionnaire list in this research is in the form of structured questions. The questionnaire is closed, in which the answer has been decided before and respondents are not allowed to give other answers. Then, their responds to this questionnaire is measured by 5 (five) likert scale range. 
Population is all available objects in a research. Population in this research is HR in Setda of Semarang Regency that consists of 105 people. This research is using census method where all available population is selected as sample, therefore based on census method, this research is using 105 respondents.

Variables in this research are 1) Social Capital that is measured through 5 indicators like having commitment to organization, managing organization's goal sincerely, working seriously, possessing teamwork spirit, and considering information and ideas in controlling work tasks (Nahapiet dan Ghosal, 1998); 2) Innovative behaviour that is measured by 4 indicators like thinking creatively, feeling happy to do new things, prioritising work execution, showing innovative menner (Bysted, 2013); 3) Information technology that is measured by 3 indicators like information system quality, information connection speed, and information system convenience And 4) SDM performance that is measured by 5 indicators like being able to improve work goal, being able to finish work on time, being able to create innovation in finishing work, being able to create creativity in finishing work, and being able to minimize work failure (Mas'ud, 2014).

\section{DATA ANALYSIS RESULT Validity Test}

Validity test is used to measure questionnaire validity. A questionnaire is said to be valid when it can reveal something that is measured by that questionnaire (Ghozali, 2005). Validity test by SmartPLS 3 programme is done by using convergent and discriminant validity measurement.

Convergent validity from that measurement model with reflective indicator is scored according to correlation between item score/component score that is estimated by SmartPLS 3 Software. Based on test result by using SmartPLS 3 on Table 1, it is known that all indicators on social capital variable, innovative behaviour, and HR performance comprise factor loading above 0.5. It means all variable indicators in this research are valid, therefore it can be used in this research.

Discriminant validity from measurement model with reflective indicator is scored based on outer loadings measurement with construct. While outer loadings result from data processing using SmartPLS 3 is: 
Table 1. Outer Loadings

\begin{tabular}{|c|c|c|c|}
\hline & HR Performance & Innovative Behaviour & Social Capital \\
\hline KSDM1 & 0,638021 & & \\
\hline KSDM2 & 0,614412 & & \\
\hline KSDM3 & 0,889109 & & \\
\hline KSDM4 & 0,889109 & & \\
\hline KSDM5 & 0,638267 & & \\
\hline PI1 & & 0,661276 & \\
\hline PI2 & & 0,653290 & \\
\hline $\mathrm{PI} 3$ & & 0,561771 & \\
\hline PI4 & & 0,801789 & \\
\hline SC1 & & & 0,549553 \\
\hline $\mathrm{SC} 2$ & & & 0,668336 \\
\hline $\mathrm{SC} 3$ & & & 0,924534 \\
\hline SC4 & & & 0,924534 \\
\hline SC5 & & & 0,900598 \\
\hline
\end{tabular}

Source: Processed primary data, 2017

Based on Table 1, it is known that construct correlation for social capital, innovative behaviour, and HR performance each of their indicator is higher than 0.5, so the construct in the estimated model fulfils discriminant validity criteria.

\section{Reliability Test}

Reliability test is done by looking at composite reliability from indicator block that measures the construct. Composite Reliability result will show satisfying score when it is above 0.7. The following is composite reliability score from SmartPLS 3 output:

Table 2. Composite Reliability

\begin{tabular}{l|l|}
\hline & Composite Reliability \\
\hline HR Performance & 0,858043 \\
Innovative Behaviour & 0,767111 \\
Social Capital & 0,900945 \\
\hline
\end{tabular}

Source: Processed primary data, 2017

Table 2 shows that composite reability score for all constructs is above 0.7 that means all constructs in estimated model fulfill reliability criteria, so it can be used in the next research process.

\section{Structural Model Test (Inner Model)}

Inner model describes relation among sustainable variables based on output result from loading factor construct structure model in the form of relational graphic between social capital, innovative behaviour, and HR performance variables. It can be seen in Picture 2 as follows: 


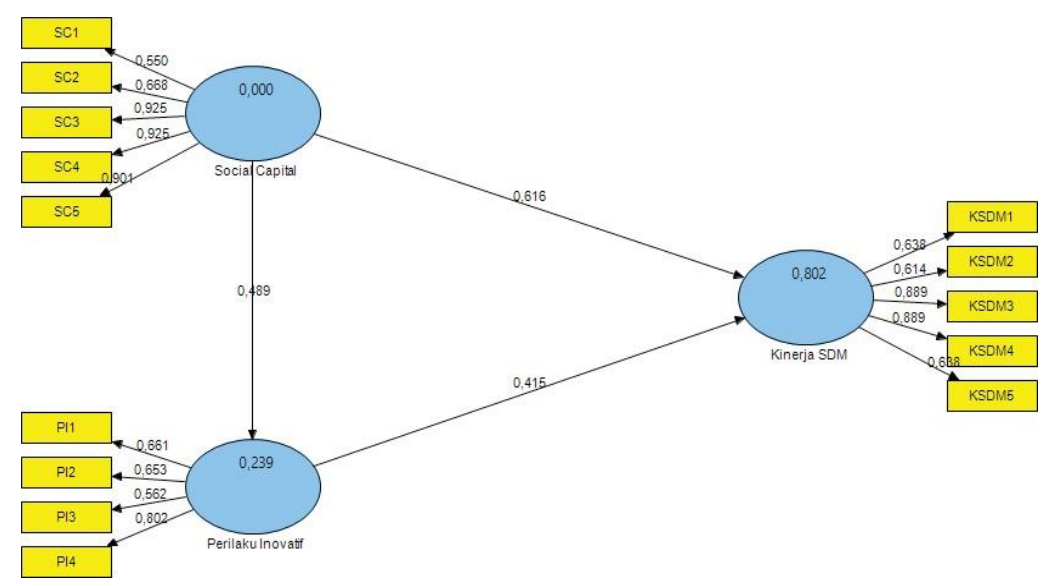

Picture 2. Structural Model Before Moderation

Table 3. R-square

\begin{tabular}{ll} 
& $R$-square \\
Social Capital & \\
Innovative Behaviour & 0,239199 \\
HR Performance & 0,801586 \\
\hline
\end{tabular}

Source: Processed primary data, 2017

Based on Table 3, it shows $R$-square score of innovative behaviour construct is 0,2392 which means social capital is able to explain innovative behaviour variants up to $23.92 \%$ and the rest $(76.08 \%)$ is influenced by other unresearched factor in this research. Then, $R$-square score can also be found in HR performance construct that makes up 0,8016 which means that social capital and innovative behaviour can explain HR performance variants as much as $80.16 \%$ and the rest $(19.84 \%)$ that is influenced by other unresearched factor in this research.

Meanwhile, to decide whether a hypothesis will be accepted or rejected, we need to compare $t_{\text {statistics }}$ and $t_{\text {table }}$ when $t_{\text {statistics }}>t_{\text {table, }}$ therefore the hypothesis is accepted. More detailed information is explained in the following Table 4:

Table 4. Path Coefficients Before Moderation

\begin{tabular}{llll}
\hline & $\begin{array}{l}\text { Original } \\
\text { Sample }\end{array}$ & $\begin{array}{l}\text { Standard } \\
\text { Deviation }\end{array}$ & T Ctatictinc \\
Innovative Behaviour $\rightarrow$ HR Performance & 0,414511 & 0,070857 & 5,850002 \\
Social Capital $\rightarrow$ HR Performance & 0,616335 & 0,070783 & 8,707420 \\
Social Capital $\rightarrow$ Innovative Behaviour & 0,489080 & 0,062973 & 7,766535 \\
\hline
\end{tabular}

Source: Processed primary data, 2017

To know that information technology can be a moderator variable in moderating relations between innovative behaviour on HR performance, it can be seen through the following processed SmartPLS 3: 


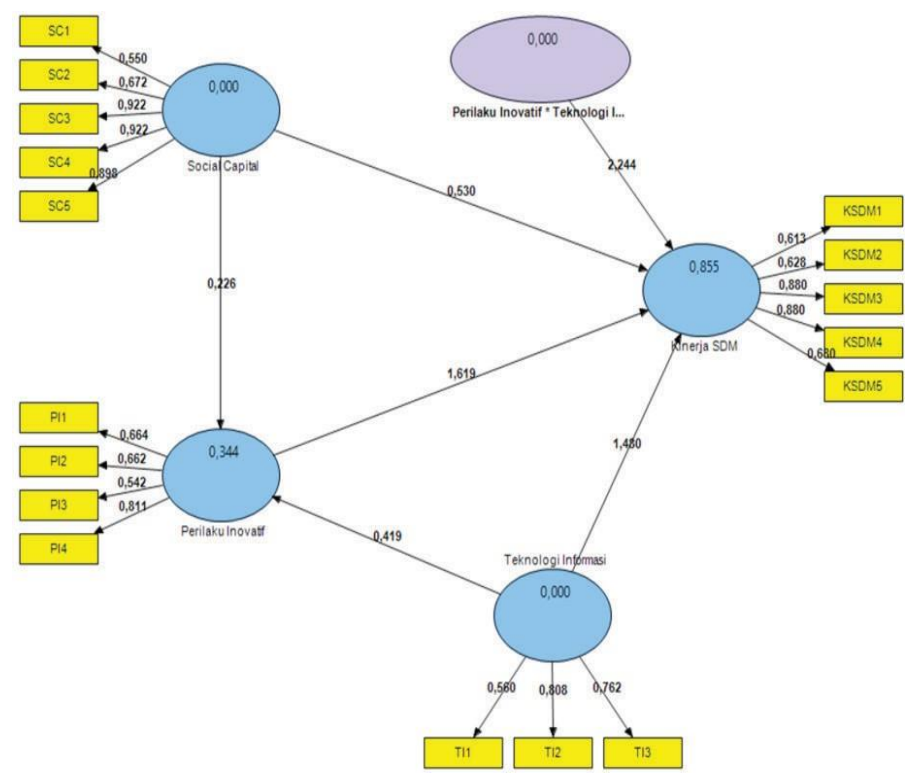

Gambar 3. Model Struktural Setelah Moderasi

Later, path coefficients result after being analysed its moderation is shown in Table 5 as follows:

Table 5. Path Coefficients After Moderation

\begin{tabular}{llll}
\hline & Original Sample & Standard Deviation & T Statistics \\
\hline Innovative Behaviour* & & & \\
Information Technology $\rightarrow$ & 2,243912 & 0,936403 & 2,396309 \\
HR Performance & & & \\
\hline
\end{tabular}

Source: Processed primary data, 2017

\section{Hypothesis Test and Discussion}

Based on relation test among construct in Table 4 and Table 5, then the proposed hypothesis in this research can be explained as follows:

\section{a) Social Capital Influence on Innovative Behaviour}

The first hypothesis proposed in this research is "When social capital is increasing, innovative behaviour is getting increased." Table 4 shows that relation between social capital and innovative behaviour is significantly influenced to each other since $t_{\text {statistics }}$ is bigger than $\mathrm{t}_{\text {table }}\left(\mathrm{t}_{\text {statistics }} 7,77>\mathrm{t}_{\text {table }} 1,66\right)$ in $5 \%$ significant level. In accordance, the first hypothesis proposed in this research is "When social capital is increasing, innovative behaviour is getting increased. "accepted. It means that to force HR innovative behaviour, management of Setda of Semarang Regency needs to increase social capital.

Social capital is viewed as working link mode and social relations (internally or externally) bonded by trusting to each other, understanding each other, supporting each other, sharing values to each other. Those behaviours as reflected in social capital enable pushing collaborative and innovative manner (Cohen dan Prusak, 2001). 
Social capital concept becomes more important in organization since it may help improving organization functional success. Social capital presence in organization has been found as significant predictor from professional innovative behaviour. Trusting to each other, understanding to each other, and sharing various values; all these values can unite and integrate one and another and also improve cooperation and cohesiveness among team members. Considering this, social capital is considered as helpful source for individual and organization to overcome stress at work place and help improving altruistic manner. Social capital can make access to source of information is getting easier, it can also help pushing individual attainment result and organization in common. Social capital give control and influence that creates solidarity and trust, it may afterwards drive collective work manner and effective interpersonal coordination. Social capital also reduces the probability of opportunistic manner and monitoring cost, drives cooperative manner, and facilitates new innovation development. The result of this research is in line with a study conducted by Gatty and Tremblay (2007); June and Kheng (2014) who proved that social capital significantly influences towards innovative behaviour.

The second hypothesis that is proposed in this research is "When social capital is increasing, HR performance is getting increased" Table 4 shows that the relation between social capital and HR performance is significant since $\mathrm{t}_{\text {statistics }}$ score is bigger than $\mathrm{t}_{\text {table }}\left(\mathrm{t}_{\text {statistics }} 8,71>\right.$ $\left.\mathrm{t}_{\text {table }} 1,66\right)$ in $5 \%$ significant level. Therefore, second hypothesis that explains "When social capital is increasing, HR performance is getting increased" is accepted as well. It means that, HR performance improvement in Setda of Semarang Regency can be well achieved through social capital.

The core perspective of social capital theory is that link network (network of relationships) is an exchange of source, information flow, and valuable knowledge transfer for all members of that link. Miller et al. (2015) found that social capital drives workers' performance improvement in organization, mainly that is related to efficiency and product quality. In other words, worker and organization competitive performance can be achieved by pushing social contact and interaction to increase social sensitivity.

Result of the research shows that effective social capital accumulation is very important for work performance as a whole. Social capital does not only connecting trust in the organization, but also affecting individual's decisions to begin work, stimulating organization innovative ability, and reinforcing organization network, thay it is expected ultimately to improve work performance to be better.

Social capital is promoting workers' life improvement all the time. The increasing of social capital can be status, knowledge, and better individual strength (in the organization or among organizations). Unique interaction through social capital in organization may create asset and performance that is very difficult to copy (Monavvarian et al., 2013).

The result of this research confirms that the result of research conducted by Ellinger et al. (2013); Hador (2016); Liu (2017) that proved social capital significantly influence on worker performance. Therefore, organization should assert more on social capital development to push and maintain worker bonding, increase productivity, and organization competitiveness. 


\section{c) Innovative Behaviour Influence on HR Performance}

The third hypothesis proposed in this research is "When innovative behaviour is increasing, HR performance is getting more increased." Based on path coefficient analysis in Table 4, it is shown that the relation between innovative behaviour and HR performance is significant since $\mathrm{t}_{\text {statistics }}$ is bigger than $\mathrm{t}_{\text {table }}\left(\mathrm{t}_{\text {statistics }} 5,85>\mathrm{t}_{\text {table }}\right.$ 1.66) in 5\% significant level. Therefore, the third hypothesis in this research that is "When innovative behaviour is increasing, HR performance is getting more increased" is also accepted. It means that innovative behaviour is viewed as one of the main factors to push HR performance improvement.

Innovative work manner is commonly framed in the context of how individual can facilitate initiative achievement and ideas introduction, process, or useful new procedures for organization. Innovative work manner through problem introductory activities, motivation, introduction, and interesting ideas realization that can improve individual ability to innovate (De Jong and Hartog, 2010).

Problem introductory and idea stimulation phase activities are behaviour oriented phase for creativity. While the promotional and new idea realization phases are work manner that orientates for work execution, where individuals are trying to promote a new idea to their friends and leaders, it is aimed at realizing the actual idea so it is expected to be applied in work role, work group, or organization. The result shows that individuals who are willing and are able to innovate will achieve greater work contribution, and at the same time, they are able to innovate continuously (Parker et al., 2006).

The worker innovative behaviour is in fact affecting organization value as well. The worker innovative behaviour will improve their performance and may lead to have higher payment and profitability. Resource theory also claims that organization needs the source ability and technology to apply new innovation strategy that will become challenge for competitor to imitate, and it enables organization to posses continuous competitive advantage and to produce better performance.

The result of this research is in line with researches conducted by Dorner et al. (2012); Leong and Rasli (2014); Yuan and Woodman (2010) that found innovative work behaviour is significantly affecting worker performance. Therefore, organization needs to improve flexibility, adaptability, sensitifity and efficiency in order to face fluctuative life changes so that it is able to achieve best performance.

\section{d) Information Technology Influence in Moderating Relation between Innovative Behaviour and HR Performance}

The fourth hypothesis proposed in this research is "Information technology is moderating of innovative behaviour influence towards HR performance." Based on Table 5 it is shown that the interaction variable between innovative behaviour and information technology on HR performance is significant since $t_{\text {statistics }}$ is bigger than $t_{\text {table }}\left(t_{\text {statistics }} 2,39>t_{\text {tabel }} 1.66\right)$ in $5 \%$ significant level. Therefore, the fourth hypothesis proposed in this study "Information technology is moderating of innovative behaviour influence towards HR performance." is also accepted. 
Information technology is an important part of social interaction that can increase innovative behaviour among teams in helping other team members to share opinions and increasing connectedness feeling among them. Effective information technology also helps team members to share information and thoughts, share opinions in terms of social context, and improve performance in organization. Information technology application can also push optimism of innovation to create competitive advantage.

In organization, adopting and using information technology is seen as a way to deal with rapid change in competition, business environment and hope to achieve competitive advantage. Leaders are getting more aware that the introduction and adoption of information technology is a key factor in improving business outcome. There are so many advantages to get with the adoption of information technology, for example reducing work costs, increasing satisfaction, and improving performance among workers (Karadag et al., 2009).

The use of information technology should not necessarily eliminate worker's job, instead it should help them to make their job more flexible. This benefit also include greater operational efficiency, improved work service, and competitive advantage attainment. The use of information technology is expected to facilitate organization and worker relation and improve that relation efficiency with quality service pogramme.

By focusing our attention on Wi-Fi technology, this research proves that Wi-Fi application is an appropriate way to improve worker innovation and satisfaction. In addition, the service through free $\mathrm{Wi}-\mathrm{Fi}$ is positively affecting performance and improving positive communication on social network. The result of this study is consistent with the finding of previous researchers, including Benitez-Amado et al. (2010); Perez-Arostegui et al. (2012); Perez-Lopez and Alegre (2012) which prove that information technology is able to stimulate work performance and overall organization productivity.

\section{CONCLUSION}

This research generally can be concluded that HR performance in Setda of Semarang Regency can be reinforced and improved through social capital, innovative behaviour, and information technology application. Based on hypothesis test that is proposed by using Structural Equation Modeling (SEM) based on SmartPLS 3 software, it can be summed up as follows:

1. The results of the first hypothesis test prove that social capital can significantly improve innovative behaviour in Setda of Semarang Regency. It means that, to push HR innovative behaviour, management of Setda of Semarang Regency needs to increase social capital.

2. In the result of the second hypothesis test, it is found that social capital can significantly improve HR performance in Setda of Semarang Regency. It means that HR performance improvement in Setda of Semarang Regency can be achieved maximally through social capital.

3. On the third of hypothesis test result, it proves that innovative behaviour can significantly improve HR performance in Setda of Semarang Regency. It means that innovative behaviour is seen as one of the main factors to encourage HR performance improvement. 
4. In the fourth hypothesis test result it is found that information technology can moderate or strengthen the relation between innovative behaviour towards HR performance in Setda of Semarang Regency.

\section{Managerial Implication}

The result of this research has implication on managerial policy as the following:

1. As regards social capital variable, organization should encourage HR to execute organization goal sincerely. It will generate sense of self belonging in order to achieve organization competitive advantage.

2. As regards innovative behaviour variable; organization should encourage HR to think creatively so that they are able to do their task and work with recent methods.

3. As regards HR performance variable, organization should encourage HR to be able to minimize mistakes in work. It is aimed at maintaining quality work attainment.

4. As regards information technology variable, organization should facilitate information network service. It aims at improving meaningful and up to date information.

\section{Research Limitation}

There are several things to note in relation to the limitation in this research, some of them are as follow:

1. The sample of this study is not too large, and moreover, all data are collected from the same respondents using the same perception measurement technique. It enables that answers given by some respondents will be bias.

2. This research is only investigating $H R$ in one institution so that generalization of research result can not be done. Therefore, HR from other cultured organization must be identified to obtain all comparison.

3. This research does not take into account gender influence, number of years in recent organization, and working group.

\section{Upcoming Research Agenda}

1. Upcoming research needs to involve leadership evaluation to measure perceptions of social capital variables, innovative behaviour, information technology, HR performance, so that the justification could be better.

2. Upcoming research needs to add other variables that are said to be able to improve HR performance, such as conformity, benevolence, helping behaviour, and learning for work. 


\section{REFERENCE}

Ali, Muhammad Asgar; Akmal Husain; dan Ahsan Zaim, (2012), "Organizational Investment in Social Capital (OISC) and Employee Job Performance: Moderation by Employee Job Engagement," International Review of Management and Bussiness Research

Balkar, Betül (2015), "The Relationships between Organizational Climate, Innovative Behavior and Job Performance of Teachers," International Online Journal of Educational Sciences

Bysted, Rune, 2013, Innovative employee behavior, European Journal of Innovative Management.

Cohen, D., \& Prusak, L. (2001). How to invest in social capital. Harvard Business Review, 79(6), 86-93.

De Jong, J. P. J., \& Den Hartog, D. (2010). Measuring innovative work behaviour. Creativity and Innovation Management, 19, 23-36.

Dörner, N., Gassmann, O., \& Morhart, F. (2012). innovative work behavior: the roles of employee expectations and effects on job performance (Doctoral dissertation).

Froiland; Nadin Dörner; Oliver Gassmann, 2012, Innovative Work Behavior: The Roles of Employee Expectations and Effects on Job Performance, European Journal of Innovative Management

Gagliardi; Luisa and Marco Percoco, (2013), "Social capital and the innovative performance of Italian provinces," LSE Research Online

Jahanian, Ramezan; Zaheed Noorozi; dan Atefe Asadi, (2012), "The impact of information technology and communication training on the performance of HR, "World Applied Science Journal

Jamshidi; Mir Hadi Moazen; dan Narjes Haghparast Kenarsari, (2015), "The effect of social capital on creativity of employees a case study," Journal of Asian Scientific Research

Leong, C. T., \& Rasli, A. (2014). The Relationship between innovative work behavior on work role performance: An empirical study. Procedia - Social and Behavioral Sciences, 129: 592-600.

Mas’ud, Fuad, 2014, Survei Diagnosis Organisasional, Penerbit BP Universitas Diponegoro

Parker, S. K., Williams, H. M., \& Turner, N. (2006). Modeling the antecedents of proactive behavior at work. Journal of Applied Psychology, 91(3), 636-652.

Pekkanen, Kimo, (2012), "The impact of communication technologies on individual workers productivity," Aalto University.

Poh Kam Wong dan Zi Lin He, 2001, The moderating effects of firm internal climate for innovation on the impact of public $R$ and D Support program, Bussiness Link.

Putri, Mita Andini dan Dyah Budiastuti, 2012, Pengaruh Kreativitas dan Perilaku Inovatif Terhadap Kinerja SDM PT Trias Sena Bhakti, Jakarta, Binus University.

Yuan, F., \& Woodman, R. W. (2010). Innovative behaviour in the workplace: the role of performance and image outcome expectations. Academy of Management Journal, 53(2), 323-342. 